\title{
Permainan sensori motorik untuk meningkatkan konsentrasi pada anak dengan ADHD
}

Utudi Kasus dan Intervensi Psikolog p-ISSN 2302-1462; e-ISSN 2722-7669 ejournal.umm.ac.id/index.php/procedia 2021, Vol 9(4):119-126

DOI:10.22219/procedia.v9i4.16459

(C) The Author(s) 2021

(c)(1) 4.0 International license

\author{
Nur Rahmatul Azkiya ${ }^{1}$
}

\begin{abstract}
The subject is a child with ADHD disorder with problems of lack of concentration and attention that is easily distracted. This affects performance in school and schoolwork that is not completed. Sensory Motor Play was done to improve the concentration of subjects so that their performance in school becomes better. This intervention uses a wide variety of games so that the subject was not easily bored and involves physical activity. The results of the intervention found that the concentration of the subject increased which was characterized by several completed tasks, showed the behavior of being able to wait in line and be able to control their voice.
\end{abstract}

\section{Keywords}

ADHD child, concentration, sensory motor play

\section{Pendahuluan}

Attention deficit hyperactivity disorder (ADHD) merupakan suatu gangguan yang ditandai dengan ketidakmampuan mempertahankan perhatian, mengatur tingkat aktivitas, dan mengontrol tingkah laku impulsif, inti dari gangguan ini adalah kurang atau tidak adanya perhatian, hiperaktifitas, dan impulsivitas (Soetjiningsih \& Ranuh, 2015). ADHD merupakan suatu kelainan atau gangguan yang ditandai dengan ketidakmampuan berkonsentrasi, tidak mau diam, terus menerus berbicara, gelisah, biasanya rentang perhatiannya sangat pendek dibandingkan temanteman seusianya (Abdurrahman, 2007). ADHD merupakan suatu gangguan yang dialami oleh anak sampai dewasa. ADHD ditandai dengan ketidakmampuan mempertahankan perhatian, gelisah dan biasanya disertai gejala hiperaktif dan tingkah laku impulsif. Anak dengan gangguan hiperaktivitas tidak mampu memusatkan perhatian dalam jangka waktu yang lama yang mengakibatkan munculnya beraneka ragam tingkah laku disruptif dan impulsif. Anak-anak selalu berlari, berbicara tanpa memperhatikan apakah pembicaraannya cocok atau tidak. Gangguan hiperaktivitas ini dapat terlihat ketika anak berusia sebelum 7 tahun (Semiun, 2006).

Terdapat beberapa simtom dari gangguan hiperaktivitas, simtom pertama adalah ketidakmampuan dalam mempertahankan perhatian. Anak-anak yang mengalami gangguan hiperaktivitas sulit untuk mengikuti petunjukpetunjuk yang diberikan, karena perhatiannya mudah sekali beralih. Sehingga yang terjadi adalah tidak dapat menyelesaikan tugas-tugas yang diberikan. Simtom kedua adalah kesulitan-kesulitan berat yang dialami disekolah, seperti dalam bidang akademik. Hal ini disebabkan karena ketidakmampuan dalam belajar serta tingkah laku yang seringkali mengganggu atau merusak. Anak-anak yang mengalami gangguan ini tidak dapat mengikuti petunjukpetunjuk yang diberikan sehingga penyelesaian suatu tugas terhambat dan perhatiannya mudah teralihkan. Ciri khas lainnya adalah tingkat aktivitas yang sangat tinggi dan sulit untuk duduk tenang, selalu bergerak seolaholah mereka digerakkan oleh mesin berkecepatan tinggi (Semiun, 2006).

Individu dengan ADHD sering mengalami masalah komorbid lainnya seperti gangguan menentang, gangguan belajar, membaca ejaan, tulisan, dan aritmatika. Anak dengan ADHD menunjukkan penurunan ukuran korteks prefrontal sehingga mengalami hambatan pada respon dan memori (Daley \& Birchwood, 2010). Penelitian terkait defisit neuropsikologis yang mendasari ADHD menjelaskan bahwa ADHD merupakan kelainan disregulasi pemikiran dan tindakan yang berkaitan dengan kontrol yang buruk. Interaksi gejala ADHD dengan masalah komorbid dan neuropsikologis menunjukkan bahwa individu dengan ADHD cenderung mengalami masalah dalam ranah akademis yang biasanya ditandai dengan perilaku lalai, mengganggu, agresif, memiliki permasalahan dengan memori, perencanaan, dan organisasi (Schachar et al., 2000).

\footnotetext{
${ }^{1}$ UPTD Perlindungan Perempuan dan Anak DP3AKB, Kota Balikpapan, Kalimantan Timur

Korespondensi:

Nur Rahmatul Azkiya, UPTD Perlindungan Perempuan dan Anak DP3AKB, Kota Balikpapan, Kalimantan Timur, Indonesia

Email: kikyazkiya@gmail.com
} 
Gejala klinis pada anak dengan gangguan ADHD bervariasi bergantung pada usia dan tipe gangguan. Pada anak prasekolah, gejala tersebut dapat dilihat dari aktivitas sering berlebihan, tidak dapat diam, berlari-lari, melompatlompat, tidak dapat bermain dengan tenang, tidak dapat menyelesaikan permainannya, mudah marah, tidak sabar menunggu antrian, dan berkelahi, sehingga sangat dibutuhkan pengawasan yang lebih ketat karena rawan akan terjadinya kecelakaan. Di sekolah, gejala yang sering terlihat adalah seperti tidak mau duduk diam di tempatnya, tidak menyelesaikan tugas sekolah, melawan guru sehingga berujung pada nilai akademik rendah (Soetjiningsih \& Ranuh, 2015). Beberapa penelitian menunjukkan bahwa anak dengan ADHD seringkali mengalami gangguan pada konsentrasinya. Gangguan konsentrasi pada anak ADHD terlihat pada perilaku tidak mendengarkan guru, seringkali melihat teman-temannya, mengganggu teman-temannya, dan melakukan kegiatan diluar kelas. Kondisi anak dengan hiperaktifitas menunjukkan adanya disfungsi neurologis, dimana gangguan tersebut merupakan ganguan yang disebabkan oleh kerusakan kecil pada sistem saraf, sehingga rentang konsentrasi anak dengan ADHD menjadi sangat pendek dan sulit dikendalikan (Anjani, 2008).

Gangguan konsentrasi pada anak ADHD pada dasarnya merupakan suatu permasalahan biologis, namun hal tersebut memiliki faktor risiko yang juga terletak pada faktor lingkungan (Biederman et al., 2008). Permasalahan yang berkaitan dengan gangguan konsentrasi yang seringkali dialami oleh anak ADHD dapat mempengaruhi performa anak di sekolah, dimana salah satunya adalah penurunan pada nilai akademik anak (Barry et al., 2002). Gangguan konsentrasi yang dialami anak dengan ADHD berkemungkinan akan menghambat performa anak pada bidang akademik. Oleh karena itu perlu adanya intervensi yang tepat guna meningkatkan konsentrasi pada anak dengan ADHD.

Beberapa peneliti melakukan uji coba intervensi yang digunakan untuk meningkatkan konsentrasi pada anak salah satunya adalah melalui play therapy. Bermain selain dapat melatih meningkatkan konsentrasi anak, juga dapat menyalurkan energi berlebih dari anak dengan ADHD. terapi bermain dapat dijadikan sebuah pendekatan terapi yang efektif untuk berbagai gangguan anak termasuk didalamnya anger management, agresif, school difficulties, ADHD, dan ADD (Nderi et al., 2010). Studi lain menyebutkan bahwa terapi bermain memiliki dampak positif pada internalisasi permasalahan perilaku, konsep diri, dan kepatuhan. Terapi bermain dapat mengontrol impulsivitas dimana pada prosesnya melibatkan keterampilan kognitif dan dapat menyebabkan penurunan hiperaktifitas pada ADHD serta dapat meningkatkan perhatian anak ADHD (Barzegary \& Zamini, 2011).

Adapun keterkaitan antara terapi bermain dengan konsentrasi anak ADHD adalah unsur terapeutik yang terkandung dalam permainan tersebut. Bermain merupakan sutau media komunikasi yang efektif dan alami dimana saat proses bermain terjalin interaksi didalamnya. Melalui bermain orang dewasa diperkenankan untuk memasuki dunia anak dan menunjukkan bahwa mereka diterima di lingkungan permainan anak, dengan begitu orang dewasa dapat menjadi pengamat terkait perkembangan anak. Selain itu bermain juga dapat mengurangi kecemasan dan dapat dijadikan sebagai media untuk melepas kepenatan (Iswinarti, 2010). Berdasarkan urgenitas bahwa ADHD dapat menghambat performa akademik anak, maka kasus ini perlu perhatian khusus dan perlu ditemukan varian intervensi lain untuk meningkatkan konsentrasi pada anak dengan ADHD, maka terapi dengan sensori integrasi akan dikombinasikan dengan play therapy.

\section{Metode Asesmen}

Asesmen dilakukan untuk membantu penegakan diagnosa pada subjek. Asesmen yang telah dilakukan antara lain; wawancara, observasi, dan tes psikologi. Wawancara dilakukan terhadap orang tua subjek untuk memperoleh data yang akurat terkait kondisi subjek. Observasi dilakukan kepada subjek saat di rumah. Hal ini dilakukan untuk memperoleh informasi terkait perilaku dan aktifitas, termasuk didalamnya hiperaktifitas dan impulsifitas pada subjek selama di rumah

Tes psikologis yang digunakan adalah CPM, Grafis, ADHD checklist, dan conners parent scale. CPM dilakukan untuk mengetahui kapasitas intelegensi subjek, tes grafis dilakukan untuk melihat pola kepribadian pada subjek, sementara ADHD checklist dan conners parent scale digunakan untuk mengetahui simtom-simtom ADHD pada subjek. Penegakan diagnosa juga dilakukan dengan menggunakan DSM V.

\section{Presentasi Kasus}

Subjek merupakan anak laki-laki berusia delapan tahun kelas dua sekolah dasar di Kota Malang. Subjek dikeluhkan oleh pihak sekolah bahwa tidak dapat berkonsentrasi sehingga mempengaruhi pada nilai akademik yang semakin menurun. Tugas-tugas sekolah yang diberikan juga sering kali tidak tuntas. Subjek juga mudah sekali teralihkan perhatiannya jika mendengar suara-suara ataupun orang lain yang sedang melintas didepan kelasnya. Didalam kelas subjek tidak dapat duduk dengan tenang sehingga subjek cenderung mengganggu teman-temannya yang sedang mengerjakan tugas.

Atas dasar beberapa keluhan tersebut pada akhirnya subjek disarankan untuk mengikuti kelas inklusi yang merupakan program baru di sekolahnya, namun orang tua subjek tidak menyetujui sebelum subjek mendapatkan diagnosa dari profesional dan diharuskan untuk mengikuti kelas inklusi disekolah. Alasan tersebut kemudian orang tua subjek memeriksakan kondisi subjek.

Tidak ditemukan adanya hambatan pada perkembangan subjek, subjek berkembang sesuai dengan usia perkembangannya. Ibu subjek juga tidak mengalami gangguan atau sakit ketika mengandung subjek. Artinya gejala ADHD 
yang dialami subjek tidak disebabkan karena genetik ataupun hambatan pada perkembangan subjek. Kemungkinan ADHD pada subjek disebabkan oleh faktor lingkungan. Ibu subjek telah menyadari bahwa subjek menunjukkan perilaku hiperaktif sejak usia subjek tiga tahun, saat itu ibu subjek mengaggap hal tersebut biasa saja karena saat itu ibu subjek tengah disibukkan merawat kakak subjek yang terkena penyakit polio. Hal inilah yang memungkinkan simtom-simtom ADHD muncul pada subjek. Seperti penelitian yang dilakukan oleh Mulligan bahwa lingkungan rumah memiliki pengaruh pada gejala hiperaktif dan impulsifitas pada anak-anak, meskipun pengaruhnya kecil namun signifikan (Mulligan et al., 2011).

Perilaku hiperaktif subjek yang menurut ibunya telah terlihat sejak usia tiga tahun berlanjut sampai usia subjek berada pada tahapan usia sekolah. Saat sekolah subjek seringkali tidak memperhatikan guru dikelas, mengganggu teman-temannya saat teman-temannya mengerjakan tugas sekolah, tugas sekolah subjek tidak pernah tuntas, dan perhatian subjek mudah teralihkan. Faktor-faktor tersebut yang pada akhirnya membuat performa akademik subjek semakin menurun. Subjek juga seringkali mendapat catatan khusus dari gurunya di setiap buku tugas sekolahnya, catatan khusus tersebut bertuliskan bahwa tugas subjek tidak tuntas karena subjek mengganggu teman atau ribut dikelas.

Saat dirumah perilaku subjek tidak jauh berbeda dengan perilaku subjek di sekolah, saat waktunya belajar dirumah atau saat mengerjakan pekerjaan rumah, subjek cenderung tidak dapat bertahan lama, subjek dapat konsentrasi pada pekerjaan rumahnya maksimal selama lima sampai sepuluh menit, kemudian subjek beralih ke aktivitas lain seperti berlarian sambil berteriak, saat duduk pun kaki subjek selalu digerak-gerakkan. Subjek juga seringkali mengganggu kakaknya yang terkena penyakit polio hingga kakak subjek pernah jatuh dari tempat tidur. Saat dirumah ibu subjek mengakui bahwa subjek cenderung semaunya sendiri, tidak dapat patuh terhadap aturan-aturan yang berlaku dirumah, subjek tidak sabar untuk menunggu ataupun bergantian, dan juga subjek selalu mengabaikan jika mendapat teguran dari orang tua dan membantah saat dinasihati oleh orang tuanya. Subjek seringkali marah dan berteriak saat keinginan subjek tidak langsung dipenuhi oleh orang tuanya.

Kapasitas intelegensi subjek pada saat pemeriksaan termasuk dalam golongan rata-rata, hal ini menunjukkan bahwa pada dasarnya subjek dapat mengikuti instruksi meskipun pada saat penyampaiannya harus satu persatu. Kognitif subjek tidak terganggu juga ditunjukkan pada kemampuan subjek menyelesaikan soal-soal latihan dilembar kerja siswa miliknya. Hal ini artinya bahwa subjek tidak memiliki permasalahan pada kognitifnya. Pola kepribadian menunjuukkan bahwa subjek memiliki antusias yang tinggi dan juga potensi yang dimiliki subjek cukup besar, tingkah laku anak juga terlihat impulsif. Subjek juga menunjukkan adanya simtom-simtom ADHD sejak subjek berusia tiga tahun.
Pola pengasuhan yang diterapkan orang tua berbeda antara ayah dan ibu subjek. Ayah subjek cenderung memaklumi segala perilaku anaknya dan tidak pernah menegur subjek dengan nada suara yang tinggi, sementara ibu subjek hampir selalu menegur dan memarahi subjek, hal tersebut dikarenakan subjek seringkali menjahili kakaknya yang sakit ataupun berlari-larian dan berteriakteriak didalam rumah. Subjek juga seringkali acuh dan pura-pura tidak mendengarkan saat ibu subjek berbicara dengan subjek. Pemberian reward terhadap subjek cenderung kurang diberikan oleh ibu subjek, subjek lebih sering mendapatkan teguran dari ibunya. Saat belajar, sering kali subjek belajar sendiri dengan jarak yang agak berjauhan dengan kakak laki-laki subjek. Tidak mendapatkan pengawasan saat belajar menjadi salah satu faktor pemicu konsentrasi subjek mudah beralih. Hal ini dikarenakan ibu subjek seringkali disibukkan dengan pesanan kue dari para pembeli, sementara ayah subjek sering mendapatkan tugas pelatihan di luar kota, kalaupun ayah subjek berada di rumah, ayah subjek lebih banyak mendampingi kakak pertama subjek untuk belajar.

Gejala-gejala ADHD pada subjek terlihat dari perolehan skor pada conners parent scale dan ADHD reward, dimana subjek memenuhi kriteria ADHD. Hasil asesmen yang dilakukan pada subjek menunjukkan bahwa permasalahan yang dialami subjek saat ini adalah kurangnya konsentrasi, dimana gangguan konsentrasi merupakan salah satu gejala yang terdapat pada ADHD. Kurangnya konsentrasi pada subjek menyebabkan menurunnya performa akademik subjek.

ADHD sendiri merupakan salah satu gangguan psikiatri yang seringkali muncul pada anak-anak dibawah usia tujuh tahun. ADHD memiliki keterkaitan dengan komorbiditas, dimana yang paling sering muncul adalah menentang oposisional, gangguan kecemasan, gangguan konduksi, dan ketidakmampuan berlajar (Ratnasari et al., 2016). Istilah Attention Deficit Disorder (ADD) pertama sekali diperkenalkan pada tahun 1980an dalam Diagnostic and Statistical Manual of Mental Disorders (DSM) III edisi ketiga yang menjadi panduan psikiatris. Pada tahun 1994 istilah tersebut diganti Attention Deficit Hyperactivity Disorder (ADHD) merupakan gangguan perilaku yang paling banyak didiagnosis pada anak-anak dan remaja. Gejala intinya meliputi tingkat aktivitas dan impulsivitas yang tidak sesuai perkembangan serta kemampuan mengumpulkan perhatian yang terganggu (Konofal et al., 2008).

ADHD pada dasarnya merupakan gangguan yang berhubungan dengan biologis, akan tetapi berkemungkinan bahwa pola pengasuhan yang diterapkan oleh orang tua dapat berpengaruh pada perilaku anak. Pada subjek, pola pengasuhan yang diterapkan oleh kedua orang tua cenderung terdapat perbedaan antara pengasuhan ayah dan ibu. Pola pengasuhan ayah cenderung mengikuti anak, tidak menggunakan bentakan, sementara pola pengasuhan yang diterapkan ibu dirumah cenderung keras, ibu yang seringkali marah, seringkali menggunakan kata "harus", 
serta subjek yang jarang sekali menuai pujian ataupun penguatan positif dari orang tuanya. Subjek seringkali mendapatkan kata "jangan" dan "harus" dari ibu.

Pada kasus subjek, telah terlihat simtom-simtom ADHD sejak subjek berusia tiga tahun. Saat itu subjek memang tidak dapat diam dan cenderung mudah terdistraksi oleh lingkungan sekitar, subjek mudah beralih jika mendengar suara, dan juga mudah bosan. Saat itu ibu subjek menganggap kondisi subjek adalah wajar, sama seperti anak-anak lainnya. Hingga kondisi tersebut berlangsung hingga subjek memasuki usia sekolah. Saat subjek di usia sekolah, seringkali orang tua subjek mendapatkan keluhan dari guru bahwa subjek sering tidak tuntas dalam mengerjakan tugas sekolah. hal ini karena subjek cenderung mengganggu teman-temannya, subjek tidak memperhatikan penjelasan dan instruksi guru.

Saat di rumah subjek juga tidak dapat mematuhi peraturan dirumah, subjek dinilai sering seenaknya atau semaunya sendiri. Subjek cenderung mengabaikan perkataan orang tua. Subjek tidak dapat menunggu dan keinginan subjek harus dituruti saat itu juga. Piaget mengatakan bahwa seharusnya anak dengan usia delapan tahun telah mampu memahami peraturan dan mampu membedakan hal yang benar dan salah, karena dalam tahap perkembangannya usia subjek telah mampu berpikir secara logis dan dapat memecahkan masalahnya sendiri. Pola pengasuhan yang tidak satu suara antara ayah ibu, juga dapat mempengaruhi perilaku anak. Subjek diasuh oleh ayahnya secara lebih santai dan lebih lembut, sementara ibunya cenderung menggunakan kata "harus." Kondisi tersebut menyebabkan anak tidak terlatih atau tidak terbaisa untuk berkonsentrasi. Selain itu sebuah penguatan positif maupun negatif sangat mempengaruhi terbentuknya tingkah laku pada anak. Subjek jarang mendapatkan penguatan positif dari orang tuanya. Sehingga motivasional yang dimiliki subjek menjadi berkurang.

\section{Diagnosis dan Prognosis}

Berdasarkan hasil asesmen maka subjek dapat di tegakkan dengan diagnosis Attention Deficit/hyperactivity Disorder dengan permasalahan kurangnya konsentrasi pada subjek (American Psychiatric Association, 2013).

Prognosis positif karena adanya motivasi pada keluarga untuk membantu subjek dapat fokus dan patuh terhadap peraturan, subjek kooperatif selama proses intervensi berlangsung, dan juga orang-orang yang berada dirumah mampu untuk bekerja sama saat proses intervensi berlangsung.

\section{Intervensi}

Intervensi menggunakan permainan sensori motorik. permainan sensori motorik merupakan sebuah intervensi yang berasal dari sensory motor integration therapy yang dikembangkan oleh Jean Ayres. Sensory motor integration therapy merupakan sebuah intervensi dimana prosesnya melibatkan pengolahan informasi yang diterima otak dan kemudian otak akan mengintegrasikan seluruh informasi melalui sensor-sensor tubuh sehingga individu dapat berfungsi secara optimal. Anak dengan ADHD sering mengalami gangguan pada proses integrasinya, dimana dapat dilihat dari perilaku yang dianggap sebagai ciri-ciri dari ADHD yaitu inatensi, impulsivitas, dan hiperaktivitas.

Sensory integration therapy banyak digunakan oleh terapis okupasi dan terkadang oleh terapis lainnya. Terapi ini dapat digunakan dalam pengobatan anak-anak dengan gangguan perkembangan dan perilaku. Sensory integration therapy melibatkan kegiatan sensorik seperti pendengaran, penglihatan, ayunan, sentuhan dan peralatan terapi lainnya seperti bola (Zimmer \& Desch, 2012).

Teknik yang digunakan pada intervensi ini adalah play therapy dengan menggunakan pendekatan behavioral. Penggunaan teknik play therapy dipilih karena subjek dinilai lebih mudah beradaptasi dengan bermain selain itu bertujuan agar subjek merasa nyaman dan senang saat proses intervensi. Seperti pada hasil penelitian bahwa terapi bermain merupakan metode yang sangat mudah diadaptasi dan dimodifikasi sesuai dengan usia, keadaan, dan kondisi anak, juga terapi bermain memungkinkan untuk dilakukan dimana saja. Bermain juga dapat menyalurkan energi berlebih yang terdapat pada anak ADHD. Proses terapi menggunakan bermacam-macam permainan, tujuannya agar anak tidak mudah jenuh dan dapat selalu antusias menjalani proses intervensi (Boyd Webb, 2011). Pemilihan permainan pada proses terapi juga dipertimbangkan atas unsur pertama, permainan mengandung aspek konsentrasi, kedua permainan melibatkan motorik anak, dan ketiga, permainan dapat dilakukan lebih dari dua orang. Urutan permainan juga dipertimbangkan berdasarkan kesulitan pada proses bermain. Adapun tahapan dalam proses permainan sensori motorik adalah sebagai berikut:

Sesi I: Bermain tangkap bola. Kegiatan pada sesi satu diisi dengan bermain bola dengan menangkap dan melemparkan bola dengan aturan apabila subjek gagal dalam permainan ini maka harus mengulang dari awal bermain. Permainan ini mulanya diikuti oleh dua orang yaitu subjek dan terapis. Peraturan pada permainan ini adalah subjek diminta untuk berdiri tegak, kemudian subjek melempar bola kearah terapis dan sebaliknya. Setelah permainan dapat dengan lancar dilakukan oleh dua orang, maka anggotanya ditambah menjadi tiga orang dan masih menggunakan satu bola, kemudian ditambah lagi menjadi empat orang dengan menggunakan dua bola.

Pada permainan ini mengandung beberapa unsur yakni; berdiri tegak, melatih anak untuk dapat mentaati peraturan permainan dan melatih mengurangi perilaku hiperaktivitas; melempar dan menangkap bola, melatih subjek untuk dapat berkonsentrasi terhadap sasaran bola dan bola yang akan subjek tangkap; selanjutnya latihan motorik kasar yakni saat anak melempar dan menangkap bola; yang terakhir adalah berlatih menunggu antrian yang dapat 
dilihat saat permainan diikuti lebih dari dua orang, subjek belajar menunggu giliran baik dalam melempar atau menangkap bola dengan posisi tetap berdiri tegak.

Sesi II: Bermain bola seperti badut. Pada sesi ini kegiatan yang dilakukan adalah bermain bola layaknya seorang badut. Permainan ini dimainkan oleh satu orang saja yaitu hanya subjek. Subjek diminta untuk memainkan dua buah bola dengan cara satu bola dilempar keatas kemudian ditangkap dan saat menangkap bola, bola lainnya dilempar keatas. Peraturan dalam permainan ini adalah subjek harus berdiri tegak, dan memainkan bola sebanyak lima kali, jika ditengah proses bermain subjek gagal maka harus diulangi dari hitungan pertama. Setelah lima hitungan berhasil, maka dinaikkan frekuensinya menjadi enam hitungan kemudian tujuh sampai dengan bermain dengan 10 hitungan.

Pada permainan ini terkandung beberapa hal didalamnya, yaitu; pertama subjek belajar untuk memetuhi aturan permaian, kedua subjek belajar mengontrol energinya saat melempar bola, yang ketiga subjek membutuhkan konsentrasi lebih tinggi daripada permainan sebelumnya, karena pada permainan ini konsentrasi subjek akan terbagi pada saat subjek menangkap dan melempar bola.

Sesi III: Bermain bowling. Pada sesi ini subjek diminta untuk menggelindingkan bola ke arah pion bowling, sehingga nantinya pion bowling akan jatuh karena bola yang digelindingkan tersebut. Aturan pada permainan ini adalah subjek harus berhasil menjatuhkan 5 buah pion bowling yang telah disusun berbaris kebelakang. Hal yang terkandung pada permainan ini adalah, subjek belajar untuk mengendalikan energinya saat menggelindingkan bola, kedua subjek belajar mematuhi aturan permainan, ketiga subjek belajar untuk menunggu antrian, keempat subjek melatih konsentrasinya saat menggelindingkan bola kearah pion bowling, kelima melatih subjek untuk bertanggung jawab menata ulang pion bowling yang berhasil dijatuhkan, agar pemain berikutnya dapat melanjutkan permainan, keenam adalah latihan motorik kasar pada saat menggelindingkan bola. Permainan ini dilakukan dengan jumlah peserta empat orang.

Sesi IV: Uno stacko. Pada sesi empat permainan yang dimainkan adalah uno stacko, peraturan pada permainan ini adalah setiap pemain mengambil satu batang stacko sesuai dengan peraturan bermain uno. Pada saat mengambil stacko, diharapkan agar tidak menjatuhkan tumpukan stacko yang telah disusun. Permainan ini dilakukan oleh empat orang pemain. Hal-hal yang terkandung dalam permainan ini adalah pertama melatih konsentrasi subjek pada saat mengambil satu stacko dan menaruhnya kembali disusunan paling atas serta tidak menjatuhkan susunan stacko, kedua subjek berlatih untuk mematuhi peraturan bermain.
Sesi V: Evaluasi dan terminasi. Evaluasi untuk melihat apakah intervensi yang dilakukan memberikan pengaruh positif pada subjek sehingga subjek mengalami peningkatan.

Sesi VI: Follow up. Follow up dilakukan untuk meninjau subjek, apakah intervensi yang diberikan cukup bertahan lama pada subjek dan dapat memberikan pengaruh positif pada subjek, terutama dalam hal perubahan perilaku. Follow up dilakukan dengan mengevaluasi tugas sekolah subjek.

\section{Hasil dan Pembahasan}

\section{Hasil}

Intervensi dilakukan dengan beberapa kali percobaan trial and error pada prosesnya. Mulanya subjek tidak dapat tenang saat permainan berlangsung, subjek selalu berpindah tempat dan menggerak-gerakkan kakinya, subjek tidak dapat berdiri tenang selama permainan berlangsung, subjek juga tidak dapat sabar menunggu giliran saat permainan dilakukan dengan empat orang. Namun, seiring berjalannya waktu dan dengan beberapa kali latihan, trial and error, subjek dapat mempertahankan posisi berdirinya hingga enam menit dan saat subjek mengubah posisinya atau menjadi lebih banyak gerakan yang dilakukan, subjek dapat kembali mempertahankan posisinya yang semula.

Selain itu hasil yang terlihat adalah subjek dapat menunggu giliran bermain selama proses bermain, hal tersebut juga telah melewati beberapa kali latihan hingga akhirnya subjek dapat menunggu gilirannya bermain. Kontrol diri subjek juga dilatih dalam proses intervensi ini yaitu saat bermain bola, subjek berlatih mengontrol energinya dan mengira-ngira seberapa besar energi yang harus dikeluarkan untuk melempar atau menggelindingkan bola. Hasil juga terlihat pada subjek saat berbicara, subjek dapat mengontrol volume suara saat permainan sehingga intensitas subjek berteriak menjadi berkurang. Subjek juga dapat patuh pada peraturan permainan, hal ini diajarkan kepada subjek dengan menggunakan kesepakatan bersama.

Subjek tidak langsung menunjukkan keberhasilan di setiap sesinya, membutuhkan beberapa kali percobaan hingga subjek dapat berhasil melakukan permainan sesuai dengan aturan. Pada sesi pertama yakni saat peramainan tangkap bola, mulanya subjek sama sekali tidak dapat berdiri dengan tegak, subjek selalu menggerakkan kakinya dan selalu berpindah-pindah tempat dan bergeser kekanan dan kekiri. Bola yang dilempar ke arah subjek pun sering kali tidak dapat subjek tangkap. Setelah beberapa kali percobaan dan latihan untuk dapat berdiri tegak, maka permainan ini berhasil subjek lalui.

Sama halnya dengan sesi pertama, pada sesi kedua, mulanya subjek tidak dapat melakukan permainan dengan baik. Memainkan bola seperti badut dengan cara melempar dan menangkap bola secara bergantian cukup sulit bagi subjek untuk memainkan permainan ini. Hal ini karena 
energi yang di keluarkan subjek terlalu besar sehingga sering kali subjek tidak dapat menangkap kembali bola yang dilemparkannya keatas. Setelah beberapa kali latihan mengontrol energi subjek dan perhatian subjek saat melempar dan menangkap bola, pada akhirnya subjek dapat melakukan permainan ini dengan cukup baik.

Pada sesi ketiga subjek memainkan permainan bowling, dimana subjek harus berkonsentrasi untuk merubuhkan pion bowling dengan menggunakan bola kasti. Pada awal permainan, subjek tidak dapat melemparkan bola tepat sasaran. Pada sesi ini subjek juga menunjukkan sikap duduk subjek yang selalu menggeliat dilantai. Percobaan demi percobaan terus dilakukan agar subjek dapat memusatkan konsentrasinya untuk melemparkan bola menuju pion-pion bowling. Tak jarang energi yang dikeluarkan subjek terlalu besar sehingga mengakibatkan bola memantul dan terlempar terlalu jauh. Namun dengan beberapa kali trial dan eror, pada akhirnya subjek dapat melakukan permainan ini dengan cukup baik.

Sesi selanjutnya subjek memainkan permainan uno stacko dengan melibatkan empat orang. Pada sesi ini selain melatih konsentrasi subjek untuk mengambil salah satu balok dengan tidak menjatuhkan bangunan balok, subjek juga diajarkan untuk menunggu giliran bermain. Mulanya subjek tidak dapat menunggu giliran bermain, subjek selalu ingin mendahului pemain lainnya. Berkalikali tangan subjek ditahan agar tidak mendahului pemain lainnya, dengan beberapa kali perlakuan dan percobaan, pada akhirnya subjek dapat menunggu giliran subjek untuk bermain.

Pada follow up, subjek telah mengalami peningkatan pada pengerjaan tugas sekolah, subjek dapat berkonsentrasi mengerjakan tugas sekolahnya hingga selesai, saat mengerjakan tugas sekolah, subjek dapat fokus mengerjakan selama kurang lebih 15 menit. Subjek dapat mengikuti instruksi yang diberikan kepada subjek, dan juga intensitas subjek mengganggu teman berkurang. Adapun diagram peningkatan konsentrasi subjek ditunjukkan pada Gambar 1.

\section{Pembahasan}

Penelitian menyebutkan bahwa pada anak dengan ADHD menunjukkan gangguan pada sirkuit motor, yang dapat menyebabkan masalah pada fungsi dan perhatian motorik. Hal tersebut dapat diatasi dengan intervensi berupa sensori integrasi (Mcleod et al., 2014).

Perilaku baru yang dimunculkan subjek merupakan hasil dari proses belajar trial and error, dimana pada proses terapi subjek berulang kali mencoba karena subjek melakukan kesalahan saat proses bermain. Pada proses terapi hukum-hukum belajar yang dikemukakan Thorndike pun berlaku. Hukum kesiapan dimana semakin siap memperoleh perubahan tingkah laku maka tingkah laku tersebut menimbulkan kepuasan pada diri individu. Hal ini terlihat saat subjek berhasil memainkan bola seperti badut,

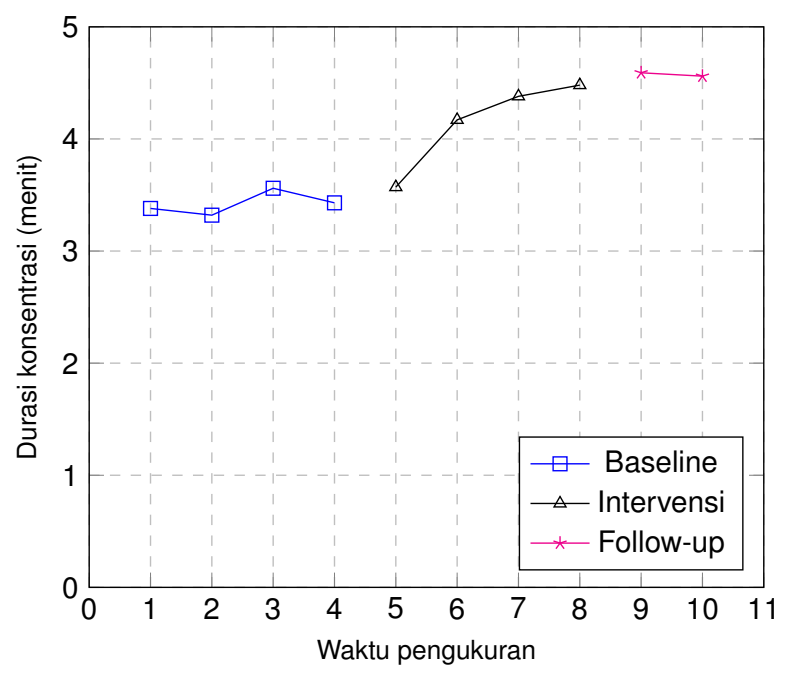

Gambar 1. Hasil intervensi.

saat subjek berhasil memainkan bolanya timbul kepuasan subjek berupa perasaan senang.

Hukum belajar Thorndike yang kedua adalah hukum latihan, dimana semakin sering tingkah laku tersebut diulang atau dilatih maka akan semakin kuat perilaku tersebut untuk diulangi. Hal ini terlihat pada setiap permainan, ketika subjek berulang kali latihan untuk melempar ataupun menggelindingkan bola maka subjek semakin mahir dalam hal tersebut. Hukum belajar yang ketiga adalah hukum akibat, dimana stimulus respon cenderung diperkuat apabila akibatnya menyenangkan dan akan melemah apabila akibatnya tidak menyenangkan. Hal ini terlihat pada proses bermain, subjek mendapatkan respon berupa pujian saat subjek berhasil menyelesaikan misinya, maka perilaku yang muncul adalah subjek ingin terus bermain.

Proses intervensi dapat berjalan dengan baik karena dipengaruhi oleh beberapa hal, yang pertama adalah ketersediaan tempat untuk melakukan intervensi yang memenuhi syarat dapat dilakukannya proses intervensi. Ruangan yang luas dan cukup kondusif menjadikan proses intervensi dapat dilakukan dengan nyaman, yang kedua adalah keterlibatan salah satu anggota keluarga yaitu kakak subjek dalam proses intervensi, sehingga subjek tidak mudah merasa bosan karena merasa ada teman bermain, yang ketiga adalah ragam permainan yang dilakukan saat proses intervensi, menjadikan subjek antusias setiap kali akan dilakukannya sesi intervensi karena permainan yang dilakukan tidak monoton, selain itu permainan yang dilakukan cukup membutuhkan energi, sehingga energi berlebih yang dimiliki anak dapat tersalurkan.

Selama proses intervensi ditemukan adanya keterbatasan-keterbatasan yang dialami salah satunya adalah faktor pendukung dari orang tua. orang tua terutama ibu cenderung tidak memberikan reward saat anak telah menunjukkan perilaku yang baik. Hal ini membuat anak merasa tidak berharga dan apa yang telah 
dilakukan anak menjadi sia-sia, sehingga anak cenderung kembali berperilaku yang tidak sesuai dengan aturan atau memunculkan perilaku impulsif. Pendampingan dan pengawasan saat jam belajar anak juga diperlukan, karena pendampingan dan pengawasan saat jam belajar anak dapat menjadi salah satu cara melatih konsentrasi anak, mengingat konsentrasi anak mudah sekali terdistraksi oleh suatu hal, sehingga diperlukan peran orang tua dalam pendampingan dan pengawasan saat jam belajar anak. Pendampingan dan pengawasan saat anak belajar juga dapat memengaruhi performa akademik anak, karena dengan didampingi orang tua saat belajar, anak merasa mendapatkan perhatian dari orang tua.

Psikoedukasi terhadap keluarga juga berperan penting dalam perubahan perilaku subjek, terutama pada penetapan aturan yang berlaku. Keluarga diberikan psikoedukasi berupa pemberlakuan kesepakatan saat menetapkan aturan dan pemberian penguatan saat subjek telah menunjukkan perubahan perilaku kearah yang lebih baik. Kohesivitas keluarga untuk saling mendukung dalam penanganan subjek berkorelasi dengan kesejahteraan emosi subjek (Weisman et al., 2005). Hal ini membantu keluarga untuk bisa melakukan penyesuaian yang tepat terhadap subjek. Peran keluarga terutama orang tua juga dapat mempengaruhi perkembangan anak terutama dalam kasus ini dapat memengaruhi peningkatan konsentrasi anak.

\section{Simpulan}

permainan sensori motorik dapat disarankan unutk membantu menangani anak dengan gangguan ADHD terutama yang mengalami permasalahan konsentrasi. Dalam permainan subjek dilatih untuk dapat mematuhi aturan-aturan yang berlaku, menunggu giliran, dan konsentrasi. Peningkatan konsentrasi menjadi faktor target yang paling penting, karena dengan meningkatnya konsentrasi pada subjek, maka performa di sekolah juga meningkat. Dukungan dari orang tua dan lingkungan sekitar memiliki pengaruh bagi subjek, karena dengan adanya dukungan dari orang lain, subjek merasakan menerima penguatan positif yang pada akhirnya berpengaruh pada perubahan perilaku subjek.

\section{Referensi}

Abdurrahman, M. (2007). Pendidikan bagi anak berkesulitan belajar. Jakarta: Rineka Cipta.

American Psychiatric Association. (2013).Diagnostic and statistical manual of mental disorders fifth edition DSM-5. Washington DC.

Anjani, A. T. (2008). Studi kasus tentang konsentrasi belajar pada anak ADHD (attention deficit hyperactivity disorder) di SDIT At-Taqwa Surabaya dan SDN V Babatan Surabaya. Jurnal BK UNESA, 1, 125-135.

Astuti, I. Y. (2013). Analisis terapi sensori integrasi terhadap perkembangan sensorimotor anak autis di pusat terapi dan sekolah berkebutuhan khusus permata bunda Surakarta. Universitas Muhammadiyah Surakarta, Surakarta.

Barry, T., Lyman, R., \& Klinger, L. (2002). Academic Underachievement and Attention-Deficit/Hyperactivity Disorder: The Negative Impact of Symptom Severity on School Performance. Journal of School Psychology, 40, 259-283. https: //doi.org/10.1016/S0022-4405(02)00100-0

Barzegary, L., \& Zamini, S. (2011). The effect of play therapy on children with ADHD. Procedia - Social and Behavioral Sciences, 30. https://doi.org/10.1016/j.sbspro.2011.10.432

Biederman, J., Petty, C. R., Wilens, T. E., Fraire, M. G., Purcell, C. A., Mick, E., ... Faraone, S. V. (2008). Familial Risk Analyses of Attention Deficit Hyperactivity Disorder and Substance Use Disorders. American Journal of Psychiatry, 165 (1), 107-115. https://doi.org/10.1176/appi. ajp.2007.07030419

Boyd Webb, N. (2011). Play therapy for bereaved children: Adapting strategies to community, school, and home settings. School Psychology International, 32 (2), 132-143. https: //doi.org/10.1177/0143034311400832

Daley, D., \& Birchwood, J. F. (2010). ADHD and academic performance: why does ADHD impact on academic performance and what can be done to support ADHD children in the classroom? Child: Care, Health and Development, 36 4, 455-464. https://doi.org/10.1111/j.13652214.2009.01046.x

Dunbar, S. B., Carr-Hertel, J., Lieberman, H. A., Perez, B. S. R., \& Ricks, K. (2012). A Pilot study comparison of sensory integration treatment and integrated preschool activities for children with autism. Internet Journal of Allied Health Sciences and Practice. https://doi.org/10.46743/1540-580x/ 2012.1407

Iswinarti. (2010). Nilai-nilai terapiutik permainan tradisional: engklek pada anak usia sekolah dasar. Malang: UMM Press.

Konofal, E., Lecendreux, M., Deron, J., Marchand, M., Cortese, S., Zaïm, M., ... Arnulf, I. (2008). Effects of iron supplementation on attention deficit hyperactivity disorder in children. Pediatric Neurology, 38 (1), 20-26. https://doi.org/ 10.1016/j.pediatrneurol.2007.08.014

Mcleod, K., Langevin, L. M., Goodyear, B., \& Dewey, D. (2014). Functional connectivity of neural motor networks is disrupted in children with developmental coordination disorder and attention-deficit/hyperactivity disorder. NeuroImage: Clinical, 4. https://doi.org/10.1016/j.nicl.2014.03.010

Mulligan, A., Anney, R., Butler, L., O’Regan, M., Richardson, T., Tulewicz, E., ... Gill, M. (2011). Home environment: Association with hyperactivity/impulsivity in children with ADHD and their non-ADHD siblings. Child: Care, Health and Development, 39, 202-212. https://doi.org/10.1111/j. 1365-2214.2011.01345.x

Nderi, F., Heidarie, A., Bouron, L., \& Asgari, P. (2010). The Efficacy of Play Therapy on ADHD, Anxiety and Social Maturity in 8 to 12 Years Aged Clientele Children of Ahwaz Metropolitan Counseling Clinics. Journal of Applied Sciences, 10. https://doi.org/10.3923/jas.2010.189.195 
Ratnasari, N. D., Kaunang, T. M. D., \& Dundu, A. E. (2016). Komorbiditas pada anak gangguan pemusatan perhatian dan hiperaktivitas (GPPH) pada 20 Sekolah Dasar di Kota Manado. E-CliniC, 4 (1). https://doi.org/10.35790/ecl.4.1. 2016.11009

Schachar, R., Mota, V. L., Logan, G. D., Tannock, R., \& Klim, P. (2000). Confirmation of an inhibitory control deficit in attention-deficit/hyperactivity disorder. Journal of Abnormal Child Psychology, 28 (3), 227-235. https://doi.org/10.1023/ a:1005140103162

Semiun, Y. (2006). Kesehatan mental. Yogyakarta: Kanisius.

Soetjiningsih, \& Ranuh, I. N. G. (2015). Tumbuh kembang anak (2nd ed.). Jakarta: EGC.

Waiman, E., Gunardi, H., Sekartini, R., \& Endyarni, B. (2011). Sensori intergrasi: Dasar dan efektifitas terapi. Sari Pediatri, 13(2), 129-136. https://doi.org/10.14238/sp13.2.2011.12936
Weisman, A., Rosales, G., Kymalainen, J., \& Armesto, J. (2005). Ethnicity, family cohesion, religiosity and general emotional distress in patients with schizophrenia and their relatives. The Journal of Nervous and Mental Disease, 193, 359-368. https://doi.org/10.1097/01.nmd.0000165087.20440.d1

Zimmer, M., \& Desch, L. (2012). Sensory integration therapies for children with developmental and behavioral disorders. Pediatrics, 129 (6), 1186-1189. https://doi.org/10.1542/ peds.2012-0876 